\title{
PENGEMBANGAN BAHAN AJAR MATA KULIAH KONSEP DASAR BAHASA DAN SASTRA INDONESIA BERBASIS KONTEKSTUAL STKIP PGRI LUBUKLINGGAU
}

\author{
Sri Murti ${ }^{1}$, Dian Ramadan Lazuardi ${ }^{2}$ \\ STKIP-PGRI Lubuklinggau ${ }^{1,2}$ \\ srimurti05@gmail.com ${ }^{1}$
}

Submit, 25-11-2019 Accepted, 22-12-2019 Publish, 23-12-2019

\begin{abstract}
ABSTRAK
Penelitian ini bertujuan untuk mengetahui rancangan pengembangan bahan ajar, hasil validasi, dan keefektifan penggunaan bahan ajar konsep dasar bahasa dan sastra indonesia berbasis kontekstual pada mahasiswa STKIP PGRI Lubuklinggau. Penelitian ini menggunakan pendekatan R\&D (research and development) model Borg and Gall. Langkah-langkah pengembangan yang peneliti lakukan yaitu, penelitian pendahuluan, perencanaan pengembangan model, validasi, evaluasi, dan revisi model. Selanjutnya produk bahan ajar diujicobakan pada mahasiswa dengan langkah-langkah: 1) Uji coba portotipe, 2) Masukan awal, 3) Uji coba kelompok kecil, 4) Uji coba lapangan. Berdasarkan hasil validasi tiga orang ahli mengenai bahan ajar konsep dasar bahasa dan sastra indonesia, diperoleh hasil sebesar $80 \%$, bahan ajar berada dikategori baik. Simpulan, bahan ajar konsep dasar bahasa dan sastra indonesia berbasis kontekstual efektif digunakan dalam perkuliahan.
\end{abstract}

Kata Kunci: Bahan Ajar, Kontekstual, Konsep Dasar

\begin{abstract}
This study aims to determine the design of instructional materials development, validation results, and effectiveness of the use of contextual basic concepts of indonesian language and literature in STKIP PGRI Lubuklinggau students. This research uses the $R \& D$ (research and development) approach of the Borg and Gall model. The steps of development that researchers do namely, preliminary research, planning development models, validation, evaluation, and revision of the model. Furthermore, teaching material products are tested on students with the steps: 1) Portotype testing, 2) Initial input, 3) Small group testing, 4) Field testing. Based on the results of the validation of three experts regarding the teaching materials of the basic concepts of indonesian language and literature, the results obtained by $80 \%$, the teaching materials are in good category. The results of this study also showed that contextual based indonesian conceptual language and literature teaching materials were effectively used in lectures.
\end{abstract}

Keywords: Teaching Materials, Contextual, Basic Concepts 


\section{PENDAHULUAN}

Bahan ajar adalah alat yang digunakan dalam pembelajaran yang bisa berbentuk bahan cetakan ataupun on line. Biasanya bahan ajar dapat dikembangkan sendiri oleh pendidik dengan tujuan dapat membuat materi sesuai dengan kondisi peserta didiknya. Menurut Nugroho (2019) keberadaaan bahan ajar sangat membantu dalam kegiatan belajar mengajar, agar materi lebih tersampaikan dengan baik. Keberadaan bahan ajar membuat mahasiswa lebih tertarik untuk mempelajari materi yang diajarkan oleh dosen. Sejalan dengan pendapat Sari (2018) bahan ajar sangat menentukan dalam keberhasilan suatu pembelajaran. Maka dari itu seseorang dosen harus menggunakan bahan ajar, selain sebagai alat bantu dalam proses pembelajaran, bahan ajar bisa menambah referensi dosen mengenai materi yang diajarkan. Dalam konteks mengajar di perguruan tinggi, khususnya pada mata kuliah Konsep Dasar Bahasa dan Sastra Indonesia, seorang dosen memberikan perkuliahan dengan harapan dapat memberikan informasi dari bahan ajar yang digunakan mahasiswa. Informasi yang didapatkan tersebut diharapkan dapat membantu mahasiswa dalam mengembangkan informasi tersebut di luar perkuliahan.

Mata kuliah Konsep Dasar Bahasa dan Sastra Indonesia merupakan mata kuliah yang bertujuan untuk memberikan pemahaman serta kemampuan mahasiswa untuk menerapkan hasil kajian kebahasaan (linguistik) dalam pembelajaran bahasa dan sastra Indonesia. Mata kuliah ini bertujuan untuk menjelaskan tentang konsep bahasa Indonesia meliputi kajian ilmu Fonologi, Morfologi, Sintaksis, dan Semantik sedangkan kajian sastra meliputi jenis sastra.

Agar tujuan akhir dari perkuliahan ini tercapai, maka diperlukan bahan ajar yang sesuai dengan kebutuhan mahasiswa Program Studi Pendidikan Bahasa dan Sastra Indonesia STKIP PGRI Lubuklinggau. Kenyataannya, bahwa bahan ajar yang tersedia saat ini belum sesuai kebutuhan. Terlebih bahan ajar yang ada hanya mampu memberikan informasi secara teori tanpa memperhatikan kebutuhan mahasiswa. Bahan ajar yang tersedia pun adalah bahan ajar seadanya baik dari buku-buku atau referensi dari internet, padahal fenomena kebahasaaan dan kesusastraan yang terjadi di kehidupan sehari-hari dapat dijadikan sebagai bahan ajar. Hal inilah yang menjadi alasan peneliti ingin mengembangkan modul mata kuliah Konsep Dasar Bahasa dan Sastra Indonesia Berbasis Kontekstual pada Mahasiswa STKIP PGRI Lubuklinggau. Bahan ajar 
merupakan salah satu bagian dari sumber belajar, maka sebagai sumber belajar maka diperlukan pengelolaan yang baik dengan memperhatikan berbagai hal. Menurut Muslich (2009) pengelolaan sumber pembelajaran perlu mempertimbangkan tujuan/ kompetensi yang ingin dicapai, misalnya buku, bahan ajar untuk kompetensi kognitif, media audio untuk kompetensi keterampilan dan sumber belajar/ media pembelajaran yang dipilih dapat memudahkan pemahaman peserta didik. Sedangkan menurut Ansyhar (2011) untuk menghasilkan bahan ajar yang baik, maka penyusunannya harus sesuai kriteria yang ditetapkan sebagai berikut: a). Self Instructional yaitu mampu membelajarkan peserta didik secara mandiri. Melalui bahan ajar tersebut seseorang atau peserta belajar mampu membelajarkan diri sendiri tanpa tergantung pada pihak lain; $b$ ). Self Contained yaitu seluruh materi pembelajaran dari satu unit kompetensi atau sub kompetensi yang dipelajari terdapat di dalam satu bahan ajar secara utuh; c). Stand Alone yaitu bahan ajar yang dikembangkan tidak tergantung pada media lain atau tidak harus digunakan secara bersama-sama dengan media pembelajaran lainnya; d). Adoptive artinya bahan ajar hendaknya memiliki daya adaptif yang tinggi terhadap perkembangan ilmu pengetahuan dan teknologi; 5). User Friendly artinya bahan ajar hendaknya bersahabat dengan pemakainya.

Penelitian yang relevan yang digunakan penelitian ini adalah penelitian Nurjaya (2012) pada penelitian ini sama-sama mengembangkan bahan ajar, perbedaannya terletak pada pendekatan yang digunakan, menggunakan pendekatan jigsaw sedangkan yang akan peneliti lakukan menggunakan pendekatan kontekstual. Pada pendekatan kontekstual ini peneliti mengaitkan materi bahan ajar dengan kehidupan nyata mahasiswa, sehingga membantu mahasiswa untuk mudah memahami materi-materi yang ada di dalam bahan ajar. Penelitian relevan selanjutnya dilakukan oleh Arsanti (2018) hasil penelitian ini menjelaskan bahwa bahan ajar bermuatan nilia regius pada mata kuliah penulisan kreatif layak digunakan dalam perkuliahan. Persamaan penelitian yang dilakukan oleh peneliti adalah sama-sama melakukan penelitian pada pengembangan bahan ajar di tingkat perguruan tinggi. Sedangkan perbedaannya adalah terletak pada pendekatan yang digunakan yaitu pada pendekatan karakter dan pendekatan kontekstual. 


\section{METODE PENELITIAN}

Penelitian ini akan dilaksanakan di STKIP-PGRI Lubuklinggau Jalan Mayor Toha Kelurahan Air Kuti Kecamatan Lubuklinggau Timut I Kota Lubuklinggau. Populasi dalam penelitian ini adalah mahasiswa semester I Program Studi Pendidikan Guru Sekolah Dasar kelas A,B,C, D, dan E. Sampel penelitiannya terdiri dari 1 kelas yang diambil secara acak yaitu kelas 1B dengan jumlah mahasiswa sebanyak 37 Mahasiswa. Dosen yang menjadi subjek penelitian ini adalah dosen yang mengajar mengajar MK Konsep Dasar Bahasa Bahasa Indonesia di STKIP-PGRI Lubuklinggau sebanyak 2 orang. Pendekatan yang digunakan dalam penelitian ini adalah pendekatan kontekstual dengan menggunakan metode penelitian Research and Development model Borg and Gall. Langkah-langkah pengembangan yang peneleliti lakukan yaitu, penelitian pendahuluan yang dilakukan pada tahap awal adalah mencari potensi dan masalah. Pada tahap ini peneliti melakukan observasi dan wawancara untuk menemukan permasalahan yang dihadapi mahasiswa dan dosen. Langkah selanjutnya yaitu perencanaan pengembangan model, pada tahap pengembangan ini, bahan ajar disusun berdasarkan silabus dan RPKPS. Tahap berikutnya yaitu validasi, evaluasi, dan revisi model. Setelah melakukan validasi, evaluasi, dan revisi model, selanjutnya produk bahan ajar diujicobakan pada mahasiswa. Pada tahap ujicoba, peneliti menggunakan evaluasi formatif, hal ini bertujuan untuk memperbaiki kondisi produk sebelum menghasilkan produk akhir. Langkah-langkah evaluasi formatif terdiri dari a) Uji coba portotipe, b) Masukan awal, c) Uji coba kelompok kecil, d) Uji coba lapangan.

\section{HASIL PENELITIAN}

Hasil penelitian pengembangan bahan ajar mata kuliah Konsep Dasar Bahasa dan Sastra Indonesia melalui tiga tahap, yaitu tahap menganalisis, tahap mengembangkan, serta tahap evaluasi dan revisi. Adapun tujuan melakukan tahap-tahap tersebut untuk mendapatkan bahan ajar yang valid, praktis, dan efektif. Berikut ini tahapan-tahapan yang harus dilakukan peneliti:

\section{Analisis Kebutuhan dan Tujuan}

Analisis kebutuhan pembelajaran dilakukan untuk mengidentifikasi bahan ajar dan mengidentifikasi kesenjangan keadaan sekarang dan yang diharapkan oleh 
mahasiswa tentang bahan ajar yang memiliki kelengkapan materi dan menarik. Adapun langkah-langkah dalam menganalisis kebutuhan pembelajaran yaitu:

1. Menganalisis tujuan pembuatan bahan ajar. Pada langkah ini, analisis yang dilakukan adalah mengidentifikasi kondisi mahasiswa Program Studi Pendidikan Guru Sekolah Dasar (PGSD) kelas 1 B yang mengambil mata kuliah Konsep Dasar Bahasa dan Sastra Indonesia. Sebelumnya bahan ajar yang digunakan dosen yang mengajar adalah buku cetak dan tidak semua mahasiswa memiliki dan mampu membeli bukubuku tersebut, sehingga proses pembelajaran hanya berjalan satu arah. Dengan pengembangan bahan ajar mata Kuliah Konsep Dasar Bahasa dan Sastra Indonesia dapat membantu proses perkuliahan dan meningkatkan minat belajar mahasiswa.

2. Analisis kesenjangan keadaan sekarang dan keadaan yang diharapkan. Kesenjangan keadaan sekarang dan keadaan yang diharapkan, dimana bahan ajar yang digunakan belum memfasilitasi mahasiswa seutuhnya, diharapkan setelah adanya bahan ajar mata kuliah Konsep Dasar Bahasa dan Sastra Indonesia yang lengkap, menarik dan memfasilitasi mahasiswa bisa membantu mahasiswa dalam proses perkuliahan.

\section{Identifikasi Pembelajaran}

Setelah melakukan analisis kebutuhan pembelajaran, langkah selanjutnya yaitu melakukan analisis pembelajaran. Analisis pembelajaran dilakukan untuk menentukan keterampilan, proses, prosedur, dan tugas-tugas belajar untuk mencapai tujuan pembelajaran yang disesuaikan dengan Rencana Program Dan Kegiatan Pembelajaran Semester (RPKPS). Materi yang diambil adalah materi yang diajarkan hingga pertemuan sebelum Ujian Tengah Semester (UTS).

\section{Analisis Pembelajar (Mahasiswa) dan Konteks}

Analisis pembelajaran (siswa) dan konteks yang dilakukan oleh peneliti yaitu menganalisis kemampuan, sikap, dan karakteristik awal pembelajaran. Berdasarkan hasil analisis kebutuhan maka dapat disimpulkan bahwa mahasiswa menginginkan bahan ajar yang mencakup materi yang lengkap, sehingga untuk pernyataan mengenai setuju pengembangan bahan ajar, mereka menjawab setuju dikembangkan bahan ajar seperti modul Konsep Dasar Bahasa dan Sastra Indonesia. 


\section{Merumuskan Tujuan Performansi}

Merumuskan tujuan performansi yang dilakukan yaitu membuat tujuan instruksional, capaian pembelajaran dan manfaat bagi mahasiswa.

\section{Mengembangkan Instrumen}

Instrumen yang dibuat berbentuk soal uraian/ esai dengan tingkat jawaban mahasiswa meliputi pemahaman analisis mahasiswa. Soal dikembangkan berdasarkan tujuan pembelajaran yang didasarkan pada materi dari setiap materi.

\section{Mengembangkan Strategi Pembelajaran}

Berdasarkan informasi yang telah dikumpulkan sebelumnya, peneliti dapat menentukan strategi yang digunakan agar bahan ajar telah dirancang dapat mencapai tujuan yang telah ditentukan. Langkah awal yang dilakukan yaitu mengembangkan RPKPS untuk mengembangkan materi dalam bahan ajar ini.

\section{Mengembangkan dan Memilih Bahan Ajar}

Pada tahap ini penulis mengembangkan bahan ajar yang sesuai dengan kebutuhan pemakai yaitu dosen dan mahasiwa. Bahan ajar yang dikembangkan diharapkan dapat membantu mahasiswa dalam proses pembelajaran serta diharapkan bahan ajar yang dibuat menarik dan mudah untuk dipahami.

\section{Evaluasi Formatif dan Revisi}

Tahap terakhir dalam pengembangan bahan ajar menulis naskah drama yaitu tahap evaluasi dan revisi. Pada tahap ini evaluasi dan revisi dilakukan dalam beberapa rangkaian, yaitu a) evaluasi ahli; b) evaluasi perorangan; c) evaluasi kelompok kecil; dan d) uji lapangan.

\section{Evaluasi Ahli}

\section{Ahli Bahasa}

Validator ahli selanjutnya yaitu ahli bahasa yang juga ahli di bidangnya diambil dari salah satu dosen STKIP PGRI Lubuklinggau Dr. Y. Satinem, M.Pd. Angket yang diberikan sama dengan ahli desain yaitu angket terbuka dengan tujuh pertanyaan. Kritik dan juga saran disediakan oleh peneliti supaya peneliti mendapatkan 
masukan, dalam perbaikan bahan ajar mata kuliah Konsep Dasar Bahasa dan Sastra Indonesia. Perbaikan dari ahli bahasa antara lain: (a) sumber rujukan masih sangat terbatas; (b) ada daftar pustaka tetapi tidak ditemukan kutipan (lengkapi kutipan; (c) pada bagian awal setiap bab seharusnya digunakan cakupan seperti yang ada pada RPKPS; (d) penomoran tidak sesuai. Adapun rincian perhitungan sebagai berikut:

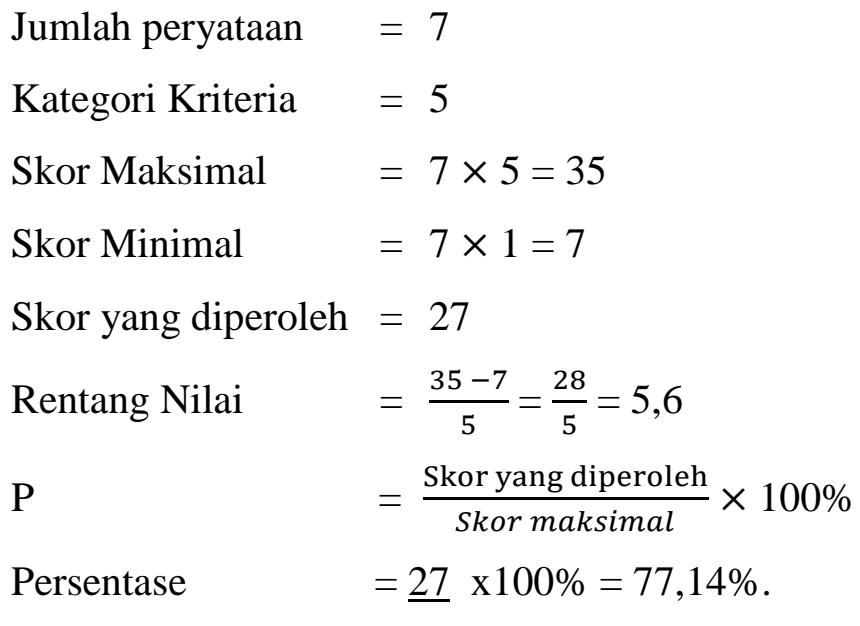

Kesimpulan komponen kelayakan isi/materi termasuk dalam kategori Baik, dengan persentase $77,14 \%$.

\section{Ahli Kelayakan Desain}

Adapun validator kelayakan desain merupakan salah satu dosen dari STKIPPGRI Lubuklinggau yang berkompeten dalam bidang desain yaitu Bapak Dr. Dodik Mulyono, M.Pd. Pertanyaan validasi desain terdiri dari sepuluh butir pertanyaan untuk mengevaluasi kelayakan penyajian Modul Mata Kuliah Konsep Dasar Bahasa dan Sastra Indonesia. Berdasarkan hasil validasi tim ahli terdapat beberapa perbaikan diantaranya; (a) pada tujuan instruksional sebaiknya ada tujuan umum dan tujuan khusus; (b) tampilan cover resolusi rendah; (c) usahakan tiap bagian ada kombinasi gambar/ grafik untuk motivasi pembaca; (d) beri keterangan setiap grafik/ gambar; (e) secara keseluruhan bahan ajar dapat digunakan dengan revisi. Adapun rincian dapat dilihat dari penghitungan di bawah ini:

$$
\begin{array}{ll}
\text { Jumlah peryataan } & =10 \\
\text { Kategori Kriteria } & =5 \\
\text { Skor Maksimal } & =10 \times 5=50
\end{array}
$$




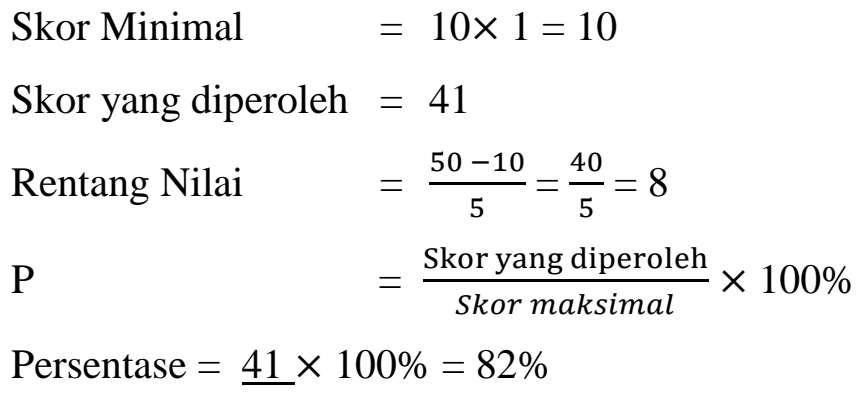

Kesimpulan komponen kelayakan desain termasuk dalam kategori baik, dengan persentase $82 \%$.

\section{Ahli Kelayakan Isi/Materi}

Evaluasi ahli materi dilakukan untuk mengetahui kelayakan cakupan materi, akuransi materi dalam memfasilitasi mahasiswa dalam kegiatan belajar mengajar yang terdiri dari tujuh pertanyaan. Evaluasi dengan menggunakan angket terbuka, sehingga ahli bisa memberikan kritik, saran, dan tanggapan. Kritik, saran dan tanggapan tersebut akan menjadi pertimbangaan dalam merevisi bahan ajar yang telah didesain. Validasi materi adalah seorang dosen yang telah ahli di bidangnya dan telah mengajar dalam kurun waktu yang lama, yaitu Ibu Dr. Rusmana Dewi, M.Pd. yang merupakan dosen Prodi Pendidikan Bahasa dan Sastra Indonesia STKIP-PGRI Lubuklinggau. Dengan rincian penghitungan sebagai berikut;



Persentase $=\underline{28} \times 100 \%=80 \%$ 35

Kesimpulan komponen kelayakan kebahasaan termasuk dalam kategori baik, dengan persentase $80 \%$. Penghitungan keseluruhan validasi dari tiga ahli dapat dilihat dari penghitungan di bawah ini: 


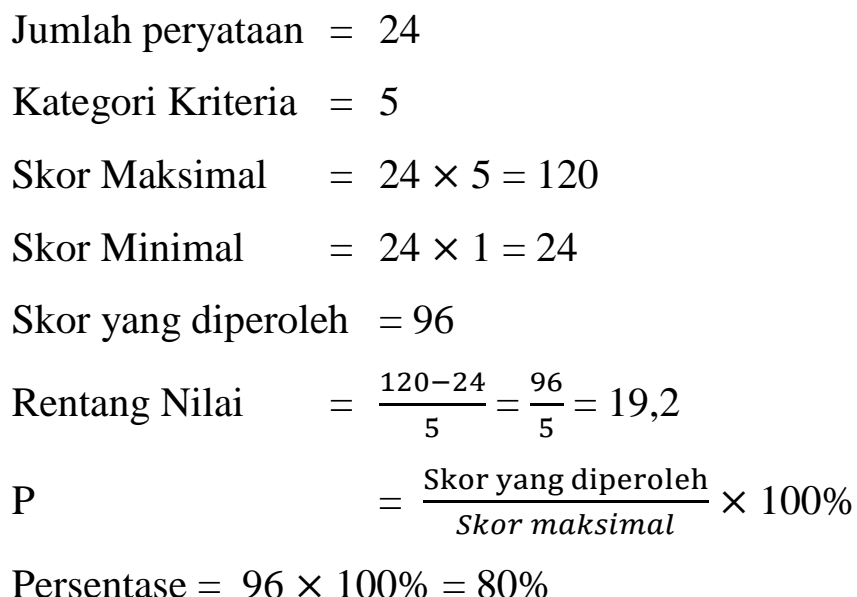

Kesimpulan seluruh komponen termasuk dalam kategori baik, dengan persentase $80 \%$.

\section{Evaluasi Prototipe}

\section{Pelaksanaan Evaluasi One To One}

Ujicoba One To One dilaksanakan pada tanggal 09 Oktober 2019, dengan melakukan wawancara kepada tiga orang mahasiswa. langkah-langkah yang dilakukan dalam evaluasi one to one adalah: a) siswa diminta untuk melihat dan membaca bahan ajar Konsep Dasar Bahasa dan Sastra Indonesia; b) Mahasiswa diminta untuk memperhatikan materi; dan c) Peneliti melakukan tanya jawab, apabila jawaban mahasiswa benar, artinya keterbacaan tinggi, produk yang dihasilkan memuat materi yang mudah dipahami oleh mahasiswa.

Hasil dari data one to one pada bahan ajar Konsep Dasar Bahasa dan Sastra Indonesia dilakukan berdasarkan empat indikator yaitu: a) kemenarikan bahan ajar; b) keterbacaan isi materi; c) penyajian gambar; d) penyajian materi dalam bahan ajar. Berdasarkan hasil dari kegiatan one to one ini, diketahui bahwa bahan ajar yang peneliti kembangkan menarik, hal ini dibuktikan dengan antusias mahasiswa terhadap bahan ajar. Kemudian bahan ajar yang peneliti kembangkan menggunakan bahasa yang sederhana sehingga tidak membuat mahasiswa merasa bingung, gambar yang diterapkan sesuai dengan kajian materi, serta memuat materi yang lengkap. Berdasarkan hasil tersebut dapat disimpulkan bahwa bahan ajar yang peneliti kembangkan dapat diterapkan pada mahasiswa dan dosen dalam melaksanakan kegiatan pembelajaran. 


\section{Pelaksanaan Evaluasi Kelompok Kecil}

Evaluasi kelompok kecil dilaksanakan pada tanggal 10 Oktober 2019, dengan memberikan angket kepada enam mahasiswa yang diambil secara acak. Angket tersebut terdiri dari 10 butir pertanyaan. Tahap ini dilaksanakan bertujuan untuk mendapatkan data atau informasi mengenai tanggapan mahasiswa terhadap bahan ajar Konsep Dasar Bahasa dan Sastra Indonesia. Kemudian instrumen yang digunakan pada evaluasi ini berupa angket tertutup, sedangkan evaluasi one to one digunakan untuk melihat kepraktisan bahan ajar merancang karya ilmiah.

Berdasarkan angket yang diberikan kepada mahasiswa, menunjukkan sikap positif terhadap bahan ajar Konsep Dasar Bahasa dan Sastra Indonesia. Skor angket diperoleh melalui tahapan:

1. Menentukan skor rata-rata

$$
\begin{aligned}
\text { Skor rata-rata } & =\frac{\text { jumlah } \text { skor angket }}{\text { jumlah } \text { mahasiswa }}=203: 6 \\
& =33,83
\end{aligned}
$$

2. Menentukan skor maksimal

Skor maksimal $=10 \times 4$

$$
=40
$$

3. Menetukan nilai minimal

Skor minimal $=10 \times 1$

$$
=10
$$

4. Menentukan nilai median

Median $=$ skor maksimal + skor minimal $: 2$

$$
\begin{aligned}
& =40+10: 2 \\
& =25
\end{aligned}
$$

5. Menentukan nilai kuartil 1

$$
\text { Kuartil } 1 \quad \begin{aligned}
& =\text { skor minimal }+ \text { median }: 2 \\
& =10+25: 2 \\
& =17,5
\end{aligned}
$$

6. Menentukan nilai kuartil 3

$$
\begin{aligned}
\text { Kuartil } 3 & =\text { skor maksimal+median: } 2 \\
& =40+25: 2 \\
& =32,5
\end{aligned}
$$


$\mathrm{P}=\frac{\text { skor yang diperolah }}{\text { skor maksimal }} \times 100$

$\mathrm{P}=\frac{33,83}{40} \times 100=84.58 \%$.

Berdasarkan hasil uji coba kelompok kecil, dapat disimpulkan bahwa respon mahasiswa terhadap bahan Konsep Dasar Bahasa dan Sastra Indonesia sangat positif dengan persentase $84,58 \%$. Hal ini menunjukan bahwa bahan ajar Konsep Dasar Bahasa dan Sastra Indonesia sudah praktis dan siap digunakan. Selanjutnya, bahan ajar Konsep Dasar Bahasa dan Sastra Indonesia diujicobakan pada ruang lingkup yang lebih luas guna melihat keefektifannya.

\section{Pelaksanaan Uji Lapangan}

Pada tahap terakhir ini, evaluasi yang dilakukan untuk mendapatkan informasi yang mendasar mengenai kualitas produk bahan ajar Konsep Dasar Bahasa dan Sastra Indonesia. Uji coba lapangan dilakukan pada 37 mahasiswa. hal ini dilakukan untuk mengetahui keefektifan dan kevalidan bahan ajar. Pelaksanaan uji coba lapangan dilakukan pada hari tanggal 16 Oktober 2019. Setelah proses kegiatan pembelajaran Konsep Dasar Bahasa dan Sastra Indonesia telah selesai, langkah selanjutnya yaitu pemberian angket untuk mengetahui respon mahasiswa setelah menerapkan bahan ajar. Angket diberikan kepada mahasiswa yang berjumlah 37 orang dengan 20 butir pertanyaan. Berikut ini hasil perolehan angket kelompok besar:

1. Menentukan skor rata-rata

$$
\begin{array}{r}
\text { Skor rata-rata } \quad=\frac{\text { jumlah } \text { skor angket }}{\text { jumlah } \text { siswa }} \\
=\frac{2599}{37} \\
=70,24
\end{array}
$$

2. Menentukan skor maksimal

Skor maksimal $=20 \times 4$

$$
=80
$$

3. Menentukan skor minimal

$$
\begin{aligned}
\text { Skor minimal } & =20 \times 1 \\
& =20
\end{aligned}
$$


4. Menentukan nilai median

$$
\begin{aligned}
\text { Median } & =\text { skor maksimal+skor minimal: } 2 \\
& =80+20: 2 \\
& =50
\end{aligned}
$$

5. Menentukan nilai kuartil 1

$$
\text { Kuartil } 1 \quad \begin{aligned}
&=\text { skor minimal+median: } 2 \\
&=20+50: 2 \\
&=35
\end{aligned}
$$

6. Menentukan nilai kuartil 3

$$
\text { Kuartil } 3 \quad \begin{aligned}
&=\text { skor maksimal }+ \text { median: } 2 \\
&=80+50: 2 \\
&=130: 2 \\
&=65
\end{aligned}
$$

$\mathrm{P}=\frac{\text { skor } \text { yang diperoleh }}{\text { skor maksimal }} \times 100$

$\mathrm{P}=\frac{70,24}{80} \times 100=87,80 \%$.

Berdasarkan hasil angket uji coba kelompok besar, dapat disimpulkan bahwa respon mahasiswa terhadap bahan ajar Konsep Dasar Bahasa dan Sastra Indonesia adalah sangat positif dengan persentase $87,80 \%$.

\section{PEMBAHASAN}

Tahapan-tahapan yang dilakukan meliputi analisis kebutuhan yang bertujuan untuk mengidentifikasi permasalahan yang dihadapi mahasiswa. Berdasarkan hasil angket analisis kebutuhan disimpulkan bahwa mahasiswa tidak memiliki buku pegangan mata kuliah Konsep Dasar Bahasa dan Sastra Indonesia. Hal ini dibuktikan dengan persentase jawaban angket sebanyak 29 mahasiswa dengan persentase sebesar 78\%. Selanjutnya berdasarkan hasil angket analisis kebutuhan bahwa mahasiswa menginginkan bahan ajar yang memiliki kelengkapan materi serta dapat dipahami dalam proses penggunaannya dengan persentase sebesar 100\% dengan 37 mahasiswa memilih jawaban ya. Setelah proses analisis kebutuhan dilakukan, maka tahapan selanjutnya yang dilakukan adalah mendesain bahan ajar berupa modul. Menurut Setyorini (2019) penyusunan buku ajar hendaknya memperhatikan beberapa tolok ukur agar menjadi buku ajar yang baik, diantaranya: gaya bahasa semi formal, struktur 
kalimat SPOK, mencantumkan TIU, TIK, dan kompetensi, disusun berdasarkan rencana pembelajaran, mencantumkan teori pakar, menggunakan rujukan, dan mengakomodasi ide-ide baru. Bahan ajar Konsep Dasar Bahasa dan Sastra Indonesia sebagai produk penelitian ini, telah sesuai dengan tolok ukur di atas.

Modul yang dikembangkan kemudian melewati tahapan uji validasi meliputi uji validasi kebahasaan (Dr. Y. Satinem,M.Pd), uji validasi desain (Dr. Dodik Mulyono, M.Pd.), dan uji validasi materi/isi (Dr. Rusmana Dewi,M.Pd.). Hasil validasi kebahasaan diperoleh angka 77,14 \% yang menunjukkan bahwa dari segi kebahasaan masih dikategori baik. Kemudian hasil validasi desain diperoleh angnka 82\% kategori baik, dan validasi isi/materi diperoleh hasil $80 \%$ yang berarti berada pada kategori baik. Sedangkan secara keseluruhan dari ketiga validasi diperoleh hasil sebesar $80 \%$ dengan kategori baik. Berdasarkan hasil uji validasi yang disimpulkan bahwa modul yang dikembangkan layak untuk digunakan meskipun ada beberapa poin dari hasil validasi yang harus diubah. Poin-poin tersebut terutama pada validasi kebahasaan mengenai kelengkapan pendukung (kata pengantar, daftar isi, dan daftar pustaka) berada pada kategori cukup yang berarti menunjukkan bahwa bagian ini perlu diperbaiki. Sementara modul Konsep Dasar Bahasa dan Sastra Indonesia berbasis kontekstual ini memiliki kelengkapan informasi yang sangat baik, terbukti berdasarkan hasil validasi desain yang memberikan nilai 5 (sangat sesuai). Dari segi isi materi berada pada kategori baik.

Setelah peneliti analisis ternyata buku bahan ajar melalui evaluasi one to one dengan 5-6 mahasiswa, didapatkan hasil bahwa bahan ajar dapat digunakan. Rata-rata jawaban mahasiswa mengenai penampilan keseluruhan modul bahan ajar Konsep Dasar Bahasa dan Sastra Indonesia sangat menarik. Kemudian terkait jawaban mengenai isi modul bahan ajar Konsep Dasar Bahasa dan Sastra Indonesia mudah dipahami dan jelas. Dari lima pertanyaan wawancara terdapat satu jawaban mahasiswa yang berbeda ketika ditanyakan mengenai kesulitan materi yang disajikan. Jawaban yang diberikan adalah tingkat kesulitan dalam memahami istilah asing yang seharusnya mereka mengharapkan istilah asing dijelaskan makna dan pengertiannya. Secara umum pendapat mahasiswa terhadap bahan ajar yang dikembangkan sangat membantu proses kegiatan belajar mengajar, materi yang disajikan dalam bahan ajar mudah dipahami karena materi dan contoh dikaitkan dengan situasi nyata mahasiswa dalam kehidupan sehari-hari. 
Dengan dan melalui bahan ajar yang tersedia, pembelajar akan memperoleh pengalaman berhubungan dengan fakta-fakta dalam kehidupan, model-model kehidupan, simbol-simbol yang dipakai dalam kehidupan. Melalui pengalaman ini pembelajar akan berlatih menilai dan mengembangkan ide-ide, memecahkan persoalan, memperoleh keterampilan, membina, dan mengembangkan sikap mental serta daya apresiatif dan kreatif.

Setelah dilakukan uji coba lapangan pada kelompok kecil, langkah selanjutnya peneliti melakukan uji skala besar. Berdasarkan hasil angket uji coba kelompok besar, dapat disimpulkan bahwa respon mahasiswa terhadap bahan ajar Konsep Dasar Bahasa dan Sastra Indonesia adalah sangat positif dengan persentase 87,80\%. Artinya bahwa modul Konsep Dasar Bahasa dan Sastra Indonesia berbasis kontekstual ini dapat digunakan dalam proses perkuliahan.

Pada tahap uji coba produk yang dilakukan sebanyak 5 pertemuan bahwa hasil belajar yang didapatkan melalui latihan soal uraian (essai) menunjukkan bahwa rata-rata nilai yang diperoleh mahasiswa berada di kategori Baik (B). Pada pertemuan pertama yang dilaksanakan pada tanggal 10 Oktober 2019 materi yang diberikan tentang "Pemakaian Tanda Baca dan Pemakaian Kata" diperoleh nilai rata-rata 77,1 yang berarti berada pada nilai Baik (B). Pertemuan berikutnya dilaksanakan pada tanggal 17 Oktober 2019 dengan materi yang diberikan "Fonologi" diperoleh nilai ratarata sebesar 76,8 yang berada pada kategori baik (B). Pada pertemuan berikutnya yang dilaksanakan sebanyak dua pertemuan pada tanggal 23 Oktober 2019 dengan materi "Morfologi" didapatkan hasil tes uraian mahasiswa sebesar 80,1 yang menunjukkan kategori sangat baik (A). Sedangkan pada materi terakhir tentang "Sintaksis" yang dilakukan sebanyak dua kali pertemuan yaitu pada tanggal 25 Oktober 2019 dan 6 November 2019, diperoleh nilai rata-rata mahasiswa sebesar 75,2 yang menunjukkan nilai baik (B).

Pada materi "Sintaksis" dilaksanakan sebanyak dua pertemuan pada masingmasing materi karena pada materi ini memiliki sub pokok bahasan yang sedikit lebih banyak sehingga tidak bisa dilaksanakan hanya dengan satu pertemuan. Sementara untuk materi "Sintaksis" nilai rata-rata mahasiswa merupakan nilai rata-rata yang paling kecil karena pokok bahasannya lebih banyak dari materi lainnya sehingga dibutuhkan pemahaman yang lebih dari mahasiswa. 
Pembelajaran dilakukan dengan menggunakan metode ceramah, demonstrasi dan penugasan. Metode ceramah dan demonstrasi bertujuan untuk mempermudah siswa agar memahami permasalahan dan materi dalam pembelajaran. metode ceramah dan demonstrasi juga akan memudahkan siswa untuk memahami materi yang sedang dijelaskan karena metode ceramah dan demonstrasi ini dilakukan secara tatap muka. Dengan demikian modul Konsep Dasar Bahasa dan Sastra Indonesia berbasis kontekstual bisa digunakan dan telah terbukti valid dengan kategori sangat baik. Selain itu respon positif dari mahasiswa terhadap modul ini yang menyimpulkan bahwa modul Konsep Dasar Bahasa dan Sastra Indonesia berbasis kontekstual ini dapat dipahami dan dapat digunakan sesuai dengan materi perkuliahan. Dari hasil tes uji coba lapangan menunjukkan hasil belajar yang baik secara klasikal.

\section{SIMPULAN}

Modul konsep dasar bahasa dan sastra Indonesia berbasis kontekstual berada dikategori baik. Modul konsep dasar bahasa dan sastra Indonesia berbasis kontekstual efektif efektif digunakan dalam perkuliahan.

\section{DAFTAR PUSTAKA}

Ansyar, R. (2011). Kreatif Mengembangkan Media Pembelajaran. Jakarta: Gaung Persada Press.

Arsanti, M. (2018). Pengembangan Bahan Ajar Mata Kuliah Penulisan Kreatif Bermuatan Nilai-Nilai Pendidikan Karakter Religius bagi Mahasiswa Prodi PBSI, FKIP, UNISSULA. Kredo; Jurnal Ilmiah Bahasa dan Sastra, 71-90. doi:https://doi.org/10.24176/kredo.v1i2.2107

Muslich, M. (2009). Pembelajaran Berbasis Kompetensi dan Kontekstual. Jakarta: Bumi Aksara.

Nugroho, A. (2019). Pengembangan Bahan Ajar LKS Menulis Pantun Berbasis Kearifan Lokal Siswa Kelas VII SMP Xaverius Tugumulyo. Jurnal KEMBARA: Jurnal Keilmuan Bahasa, Sastra, dan Pengajarannya, 1(5), 1-12. doi:https://doi.org/10.22219/KEMBARA.

Nurjaya, G. (2012, Oktober). Pengembangan Bahan Ajar Metode Pembelajaran Bahasa dan Sastra Indonesia Berbasis Pembelajaran Kooperatif Jigsaw untuk Meningkatkan Pemahaman dan Kemampuan Aplikatif Mahasiswa. Jurnal Pendidikan Indonesia, 102-111. doi:http://dx.doi.org/10.23887/jpiundiksha.v1i2.4490 
Sari, I. P. (2018). Pengembangan Bahan Ajar Struktur Teks Deskripsi Berbasis Kearifan Lokal Tempat Wisata di Lubuklinggau Siswa Kelas VII MTs. Mazro'illah Lubuklinggau. Seminar Nasional Pendidikan Bahasa Indonesia. 2. Palembang: Universitas Sriwijaya. Retrieved from http://conference.unsri.ac.id/index.php/SNBI/article/view/1307

Setyorini, N. (2019). Pengembangan Bahan Ajar Apresiasi Puisi Berbasis Nilai Bela Negara Bagi Mahasiswa Semester II Pendidikan Bahasa dan Sastra Indonesia di Universitas Muhammadiyah Purworejo. Lingua Rima: Jurnal Pendidikan Program Studi Bahasa dan Sastra Indonesia, 8(1), 41-49. doi:http://dx.doi.org/10.31000/lgrm.v8i1.1261 